\title{
THE DIFFERENCE OF BLOOD PRESSURE AND ARTERIAL STIFFNESS AFTER INTAKE OF ARABICA AND ROBUSTA COFFEE IN CONTROLLED HYPERTENSION
}

\author{
Budi S Pikir, Andrianto, Ford Ance A \\ Department of Cardiology and Vascular Medicine, Faculty of Medicine, Universitas Airlangga, Surabaya
}

\begin{abstract}
ABSTRAK
Mekanisme potensial kafein meningkatkan arterial stiffness dan berhubungan dengan peningkatan morbiditas dan mortalitas penyakit kardiovaskular. Untuk mengetahui perbedaan tekanan darah dan arterial stiffness setelah minum kopi arabika dan robusta pada penderita hipertensi terkontrol, penelitian eksperimental semu dilakukan dengan subjek penelitian pada 24 pasien hipertensi terkontrol dan 24 subjek normotensi yang dikumpulkan secara purposive sampling. Tiap subjek diberikan $\pm 10,6 \mathrm{~g}$ kopi arabika atau robusta dalam $150 \mathrm{ml}$ air dengan protokol crossover sebanyak dua kali dengan rentang waktu 5 hari. Penilaian arterial stiffness dengan ultrasonografi arteri karotis komunis dihitung menggunakan indeks beta stiffness. Tekanan darah dan arterial stiffness diukur sebelum pemberian kopi serta 30 dan 60 menit setelahnya. Pada hipertensi terkontrol, ditemukan perbedaan yang signifikan antara tekanan darah sistolik (TDS) awal, 30 dan 60 menit setelah pemberian arabica $(p 0,002)$ dan robusta (p 0,012); antara tekanan darah diastolic (TDD) awal, 30 dan 60 menit setelah pemberian arabica (p 0,004) dan robusta (p 0,025); dan antara beta stiffness index awal, 30 dan 60 menit setelah pemberian arabika (p 0,018). Namun, tidak ada perbedaan yang signifikan antara beta stiffness index awal, 30 dan 60 menit setelah pemberian robusta (p 0,104). Tidak ada perbedaan yang signifikan pada semua variabel setelah pemberian arabica dan robusta. Perbedaan signifikan ditemukan pada tekanan darah setelah asupan arabica atau robusta dan pada arterial stiffness setelah asupan arabika. Namun, tidak ada perbedaan signifikan yang ditemukan pada arterial stiffness setelah asupan robusta dan pada semua variabel setelah asupan arabika dan robusta. (FMI 2017;53:209-216)
\end{abstract}

Kata kunci: Kafein; tekanan darah sistolik; tekanan darah diastolik; arterial stiffness

\begin{abstract}
Potential mechanisms of caffeine promote large artery stiffness and associated with increased morbidity and mortality of cardiovascular disease. To find the difference of blood pressure and arterial stiffness after intake of arabica and robusta coffee in controlled hypertension, a quasi-experimental study was done enrolling 24 controlled hypertension and 24 normotensive subjects collected by purposive sampling. Subjects received $\pm 10,6 \mathrm{~g}$ caffeinated coffee in $150 \mathrm{ml}$ water with crossover protocol twice in 5 days. The assessment of arterial stiffness by obtaining ultrasound $2 D$ image of common carotid artery then was calculated with beta stiffness index. Blood pressure and arterial stiffness was measured before coffee intake and again at 30 to 60 minutes thereafter. In controlled hypertension, significant differences were found between initial systolic blood pressure (SBP), 30 and 60 minutes after arabica $(p$ 0,002) and robusta ( $p$ 0,012) intake; between diastolic blood pressure (DBP), 30 and 60 minutes after of arabica ( $p$ $0,004)$ and robusta $(p 0,025)$ oral administration; and between initial beta stiffness index, 30 and 60 minutes after arabica ( $p 0,018)$ oral administration. However, no significant difference was found between initial beta stiffness index, 30 and 60 minutes after robusta $(p 0,104)$ oral administration. No significant difference was found in all variables after arabica and robusta intake. Significant differences were found in blood pressure after arabica or robusta intake and in arterial stiffness after arabica intake. However, no significant differences were found in arterial stiffness after robusta intake and in all variables after arabica and robusta intake. (FMI 2017;53:209-216)
\end{abstract}

Keywords: Caffeine; systolic blood pressure; diastolic blood pressure; arterial stiffness

Correspondence: Budi S Pikir, Department of Cardiology and Vascular Medicine, Faculty of Medicine, Universitas Airlangga, Jalan Prof. Dr. Moestopo 47, Surabaya 60131, Indonesia. Email : bspikir@ gmail.com phone : 0811348106

\section{INTRODUCTION}

Hypertension is still a big challenge around the world. This is because hypertension is a condition often found in primary health care. In 2008, there were approximately $40 \%$ of adults $>=25$ years old diagnosed with hypertension. This number increased from 600 million people in 1980 to 1 billion people in 2008 . The highest prevalence of hypertension was in the African region, estimated at $46 \%$ in adults $>=25$ years old, while the lowest prevalence was in the United States which was $35 \%$ (WHO 2013). In 2013, the prevalence of hypertension in Indonesia of adults $>=18$ years old was $25.8 \%$ (Riskesdas 2013). The highest percentage was in Bangka Belitung (30.9\%), followed by South Kaliman- 
$\tan (30.8 \%)$, East Kalimantan $(29.6 \%)$ and West Java (29.4\%) (Balitbangkes 2013).

Globally, cardiovascular disease causes about 17 million deaths. It is one-third of total deaths each year. Complications due to hypertension are estimated to cause 9.4 million deaths annually. Hypertension is responsible for $45 \%$ of deaths from heart disease and $51 \%$ of stroke deaths (WHO 2013). Epidemiological studies have shown that hypertension was linearly related to the morbidity and mortality of cardiovascular disease, so hypertension disease should be preventable and treatable. A study mentioned that cases of hypertension that have been diagnosed by health personnel or who have been taking antihypertensive drugs in Indonesia was still low at $24.2 \%$. This showed that $75.8 \%$ of hypertension cases in the community have not been reached by health service (Rahajeng 2009).

Some lifestyle and diet factors have significant effect on hypertension, including obesity, lack of physical activity, excessive salt intake, and highly alcohol consumption (Geleijnse 2008, Torre et al 2006). Thus, lifestyle modification in addition to overcoming the primary factors that cause hypertension, is also very important role in the management of hypertension (Torre et al 2006). The hypertensive management guidelines that deal with coffee consumption as a lifestyle have not existed to date (Mesas et al 2011).

Coffee is one of the most widely consumed drinks in the world. In 1989, the level of coffee consumption in Indonesia based on LPEM UI survey result was 0.5 kilogram/capita/year. By 2015, domestic coffee consumption was estimated to reach 1.09 kilogram/ capita/year (http://www.aeki-aice.org). Adults aged 3564 years old are the largest coffee consumers, with average intake of $250 \mathrm{mg} /$ day which is equivalent to 3 cups of coffee per day (Faraq et al 2010). The most commercially consumed types of coffee are arabica and robusta (Janzen 2010). Coffee contains hundreds of different biochemical molecules which are formed during the combustion process. The important components contained in coffee are caffeine, alcohol diterpene, chlorogenic acid and other polyphenols. Caffeine is one of the main components in coffee and the levels may vary on each of the coffees (Patil et al 2011). The content of caffeine in arabica coffee is about $1.3 \%$, and in robusta about $2.3 \%$ (Janzen 2010).

Some epidemiological studies have tried to explain the effects of coffee consumption on cardiovascular function, but this issue has remained controversial to date (Patil et al 2011). There were many contradictions about the effects of caffeine on heart rate, blood pressure, and catecholamine levels in plasma (Chou
1992). The mechanism of coffee and caffeine effects on normotensive individuals cannot be identified for certain, as well as in people with hypertension (Mesas et al 2011).

Several short-term studies of caffeine suggested that there was increase in blood pressure and peripheral vascular resistance, but the tolerance was rapid. The effects of caffeine pressors are probably mainly due to the influence of caffeine on vascular resistance instead of an increase in cardiac output. Currently, there are developing opinions on the possible role of aorta in the pathogenesis of increased blood pressure, especially systolic (Mahmud \& Feely 2001). Increased blood pressure is associated with increased aortic stiffnes that increases reflection waves. Furthermore, increased aortic stiffness and increased reflection waves also have an impact on the pathogenesis of systolic hypertension (Vlachopoulos 2007). The effect of coffee on blood pressure and arterial stiffness in controlled hypertensive patients is not fully understood. This study was conducted to determine whether there were differences in blood pressure and arterial stiffness after consuming arabica and robusta coffee in patients with controlled hypertension.

\section{MATERIALS AND METHODS}

This study was quasi experimental study with crossover design. This study involved one group of controlled hypertensive patients and one group of normotensive patients who underwent three times of blood pressure and arterial stiffness examinations before, 30 minutes and 60 minutes after drinking coffee. The study was conducted at the Cardiology and Vascular Medicine Outpatient Clinic and Echocardiography Room of Dr. Soetomo Hospital, Surabaya from August to November 2015 .

The population in this study were outpatients at Heart Clinic of Dr. Soetomo Hospital, Surabaya during the period of August to November 2015. The accessible population in this study were outpatients at Heart Clinic of Dr. Soetomo Hospital, Surabaya from August to November 2015 who suffered from controlled hypertension. The sample in this study was controlled hypertension patients at Heart Clinic Dr. Soetomo Hospital, Surabaya from August to November 2015 who fulfilled the inclusion and exclusion criteria consisting of 24 people.

The inclusion criteria in this study were male or female patients aged 30 to 60 years old with history of hypertension and had undergone treatment so the blood pressure was controlled (at least 1 month), the patients 
previously drank coffee and had no complaints, willing to participate in the study and signed informed consent. While the exclusion criteria were patients with history of coronary heart disease, cerebrovascular disease, peripheral artery disease, chronic kidney disease, diabetes mellitus, and chronic liver disease. The drop out criteria were patients who did not come to Dr. Soetomo Hospital, resigned from the study, and could not be contacted by phone or through the contact person listed on medical record.

\section{Materials and tools}

The data were primary data obtained from blood pressure examination in hypertensive patient who went to Heart Clinic of Dr. Soetomo Hospital, Surabaya and echocardiography division of Cardiology and Vascular Medicine Department of Dr. Soetomo Hospital during the period of August-November 2015. Echocardiography tool used was General Electric Vivid S5 Cardiovascular Ultrasound System. The blood pressure measuring device used was Riester Nova sphygmomanometer. The materials used were arabica or robusta coffee with caffeine level of $1.27 \%$ for arabica coffee and $2.43 \%$ for robusta coffee. The levels of caffeine were examined by chromatography. A total of $\pm 10.6 \mathrm{~g}$ of coffee were dissolved in $150 \mathrm{ml}$ of water. The coffee was made with $\mathrm{Klaz}{ }^{\circledR}$ coffee machine.

\section{Implementation of study}

Patients with hypertension who came to Heart Clinic of Dr. Soetomo Hospital, Surabaya in August-November 2015 were collected. Furthermore, they were selected based on inclusion and exclusion criteria that had been determined. Patients who met the inclusion criteria were included as samples in the study and recorded. Records included: subject identity, blood pressure and pulse test results, and carotid ultrasound examination. Study's subjects were prohibited from consuming coffee 24 hours before the measurement of blood pressure and arterial stiffness.

Blood pressure measurements were performed using Riester Nova® sphygmomanometer. Measurements were made using cuffs of more than $80 \%$ of the patient's upper arm circumference. The next steps were measuring blood pressure from the patient's right arm, feeling the radial artery and pumping the cuff until the arterial pulsation was no longer palpable, and adding pressure up to $30 \mathrm{mmHg}$ above the limit. The Littman classic II stethoscope was affixed to brachial artery. The mercury was lowered slowly at a rate of $3 \mathrm{~mm} / \mathrm{sec}$. The first sound was summed up as systolic blood pressure, while the last sound before disappearing was summed up as diastolic blood pressure.
An arterial stiffness examination was performed using GE Cardiology Ultrasound Vivid S5 with an 8L vascular probe. Patients' jugular positions were identified when patients were in supine sleeping position to obtain the images of right common carotid artery. Furthermore, the measurements of right common carotid artery diameter during the systolic (largest diameter) and diastolic (smallest diameter) phases were performed in 5 cycles and the average of the results was taken. The results obtained were applied into $\beta$ stiffness parameter formula.

\section{Management and analysis of data}

The data obtained underwent the process of coding, entry, cleaning, and editing. Furthermore, the data were analyzed descriptively which included the basic characteristics of research subjects, the results of measurement of systolic and diastolic blood pressure, pulse rate, and beta stiffness index. Categorical-scale descriptive data were displayed in the form of frequency and percentage, while numerical data were displayed in mean \pm standard intersection form when data were normally distributed, or median (lowest to highest) when data were not normally distributed. The data were displayed in tabular form.

Furthermore, dependent and independent variable data were analyzed using Mann Whitney/independent T-test, Friedman/post-hoc Wilcoxon test, and Wilcoxon/pair Ttest. The whole process of data analysis were processed using SPSS program for windows in 20.0 version.

\section{Ethical clearance}

The approval from the Ethics Committee of Dr. Soetomo Hospital, Surabaya was submitted before the implementation of study. The patient's consent declaration statement was expressed in the form of signed informed consent by patients or their relatives. Patients and their relatives were not coerced and were not burdened with any costs associated with this study. Identity data and inspection results were kept secret from unauthorized parties.

\section{RESULTS}

This was quasi experimental study with crossover design to observe the difference of blood pressure and arterial stiffness after consuming arabica and robusta coffee in controlled hypertensive patients. The study was conducted for four months (August-November 2015) with purposive sampling. The total number of samples in this study was 48 subjects, with median age of 43 years old (the youngest was 30 years old and the 
oldest was 60 years old). Twenty-two persons $(45.8 \%)$ were male and $26(54.2 \%)$ were female. The median of body mass index (BMI) in controlled hypertensive group (25.7) was not significantly different from the median of IMT in normotensive group (24.25). The most widely used antihypertensive therapy in the controlled hypertensive group was calcium channel blocker (CCB) group which was $83.3 \%$.

\section{Analysis of differences in variable data on controlled hypertensive and normotensive groups with arabica coffee}

Table 1. Tabel of SBP, DBP, HR, and BSI difference analysis in controlled hypertensive and normotensive groups before and after arabica coffee administration

\begin{tabular}{lccc}
\hline Variables & $\begin{array}{c}\text { Hypertensive } \\
\text { group }\end{array}$ & $\begin{array}{c}\text { Normotensive } \\
\text { group }\end{array}$ & p value \\
\hline Initial SBP & $132(115-135)$ & $115(95-135)$ & $<0.001^{*}$ \\
SBP 30' & $140(110-150)$ & $120(100-145)$ & $<0.001^{*}$ \\
SBP 60' & $133.50(110-150)$ & $120(95-140)$ & $<0.001^{* *}$ \\
Initial DBP & $80(65-90)$ & $80(55-90)$ & $0.009^{*}$ \\
DBP 30' & $87.50(65-95)$ & $75(50-95)$ & $0.002^{*}$ \\
DBP 60' & $80(65-95)$ & $75(50-92)$ & $0.006^{* *}$ \\
Initial HR & $78(64-100)$ & $80(64-100)$ & $0.641^{*} *$ \\
HR 30' & $76(60-100)$ & $76(60-100)$ & $0.652^{*}$ \\
HR 60' & $76(64-104)$ & $76(64-100)$ & $0.771^{*}$ \\
Initial BSI & $2.59(1.49-4.60)$ & $2.07(1.04-3.33)$ & $0.003 * *$ \\
BSI 30' & $2.99(1.62-4.94)$ & $2.10(1.21-3.31)$ & $0.001^{* *}$ \\
BSI 60' & $2.79(1.27-5.30)$ & $2.35(1.15-3.63)$ & $0.006^{*}$ \\
\hline
\end{tabular}

Note: SBP: Systolic blood pressure; DBP: diastolic blood pressure; HR: heart rate; BSI: beta stiffness index; *Analyzed with Mann Whitney test; **Analyzed with independent T-test

Mann Whitney test results for abnormal distribution data showed significant differences between controlled hypertensive and normotensive groups after arabica coffee administration on initial systolic blood pressure $(\mathrm{p}<0.001)$, systolic blood pressure at 30 minutes after treatment $(\mathrm{p}<0.001)$, blood pressure of early diastolic $(\mathrm{p}$ $0.009)$, diastolic blood pressure at 30 minutes after

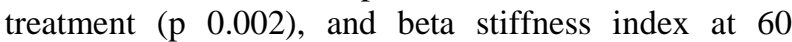
minutes after treatment ( $\mathrm{p}$ 0.006). The independent Ttest results for normal distribution data showed significant differences between controlled hypertensive and normotensive groups after arabica coffee administration on systolic blood pressure at 60 minutes after treatment $(\mathrm{p}<0.001)$, diastolic blood pressure at 60 minutes after treatment $(\mathrm{p}<0.006)$, initial beta stiffness index ( $p 0.003)$ and at 30 minutes after treatment $(p$ $0.001)$.

Analysis of differences in variable data in controlled hypertensive and normotensive groups with robusta coffee administration
Table 2. Tabel of SBP, DBP, HR, and BSI difference analysis in controlled hypertensive and normotensive groups before and after robusta coffee administration

\begin{tabular}{lccc}
\hline Variables & $\begin{array}{c}\text { Hypertensive } \\
\text { group }\end{array}$ & $\begin{array}{c}\text { Normotensive } \\
\text { group }\end{array}$ & p value \\
\hline Initial SBP & $132(105-135)$ & $115(95-135)$ & $<0.001^{*}$ \\
SBP 30' & $135(105-155)$ & $117.50(100-140)$ & $<0.001^{*}$ \\
SBP 60' & $130(105-150)$ & $115(100-150)$ & $<0.001^{* *}$ \\
Initial DBP & $80(65-90)$ & $77.50(50-85)$ & $0.002^{*}$ \\
DBP 30' & $85(60-95)$ & $75(60-90)$ & $0.004^{*}$ \\
DBP 60' & $82.50(70-95)$ & $75(55-90)$ & $0.003^{* *}$ \\
Initial HR & $80(68-100)$ & $80(68-106)$ & $0.616^{* *}$ \\
HR 30' & $78(64-100)$ & $78(60-104)$ & $0.941^{*}$ \\
HR 60' & $80(64-96)$ & $76(60-100)$ & $0.197^{*}$ \\
Initial BSI & $2.81(1.17-4.38)$ & $2.01(1.22-3.63)$ & $0.013^{* *}$ \\
BSI 30' & $2.92(1.20-5.53)$ & $2.18(1.12-3.63)$ & $0.003^{* *}$ \\
BSI 60' & $2.68(1.53-5.37)$ & $2.16(1.26-4.61)$ & $0.013^{*}$ \\
\hline Note: SBP: systolic blood pressure; DBP: diastolic blood pressure; \\
HR: heart rate; BSI: beta stiffness index; *Analyzed with Mann \\
Whitney test; **Analyzed with independent T-test
\end{tabular}

Mann Whitney test results for data with abnormal distribution showed significant differences between controlled hypertensive and normotensive groups after robusta coffee administration on initial systolic blood pressure ( $\mathrm{p}<0.001)$, systolic blood pressure at 30 minutes after treatment $(\mathrm{p}<0.001)$, baseline diastolic blood pressure ( $\mathrm{p}$ 0.002), diastolic blood pressure at 30 minutes after treatment ( $\mathrm{p}$ 0.004), diastolic blood pressure at 60 minutes after treatment ( $p 0.003)$, beta stiffness index at 30 minutes after treatment ( $p 0.003)$, and beta stiffness index at 60 minutes after treatment ( $p$ 0.013). The independent T-test results for normal distribution data showed significant differences between controlled hypertensive and normotensive groups after robusta coffee administration on systolic blood pressure at 60 minutes after treatment $(\mathrm{p}<0.001)$ and the initial beta stiffness index ( $\mathrm{p}$ 0.013).

Further statistical analysis showed that Friedman test results exhibited significant differences in initial SBP, SBP at 30 minutes after treatment and SBP at 60 minutes after treatment ( $\mathrm{p}$ 0.002). Post-hoc Wilcoxon test showed significant difference of initial SBP and SBP at 30 minutes after treatment (p 0.001), and initial SBP and SBP at 60 minutes after treatment (p 0.010). Friedman test result showed significant difference of initial DBP, DBP at 30 minutes after treatment and DBP at 60 minutes after treatment ( $p$ 0.004). The post-hoc Wilcoxon test showed a significant difference in baseline DBP and DBP at 30 minutes after treatment ( $p$ $0.025)$, and DBP at 30 minutes and DBP at 60 minutes after treatment ( $\mathrm{p}$ 0.010). Friedman test results showed no significant difference in initial pulse, pulse at 30 minutes after treatment, and pulse at 60 minutes after treatment ( $p$ 0.594). Friedman test result showed significant difference of BSI at baseline, BSI at 30 
minutes after treatment and BSI at 60 minutes after treatment ( $p$ 0.018). The post-hoc Wilcoxon test showed significant difference in baseline BSI and BSI at 60 minutes after treatment (p 0.026).

Friedman test result showed significant difference of initial SBP, SBP at 30 minutes after treatment and SBP at 60 minutes after treatment (p 0.012). Post-hoc Wilcoxon test showed significant difference of initial SBP and SBP at 30 minutes after treatment (p 0.003), and initial SBP and SBP at 60 minutes after treatment ( $\mathrm{p}$ 0.024). Friedman test result showed significant difference of initial DBP, DBP at 30 minutes after treatment and DBP at 60 minutes after treatment $(\mathrm{p}$ 0.025). The post-hoc Wilcoxon test showed a significant difference in baseline DBP and DBP at 30 minutes after treatment ( $p$ 0.024). Friedman test results showed no significant difference in initial pulse, pulse 30 minutes after treatment and pulse 60 minutes after treatment ( $p$ 0.297). Friedman test results showed no significant difference in baseline BSI, BSI 30 minutes after treatment and BSI 60 minutes after treatment (p 0.104).

\section{Analysis of differences in variable data in controlled hypertensive groups with arabica and robusta coffee}

Table 3. SBP, DBP, HR, and BSI differences in controlled hypertensive groups before and after arabica and robusta coffee administration

\begin{tabular}{lccc}
\hline \multicolumn{1}{c}{ Variables } & Arabica & Robusta & p value \\
\hline Initial SBP & $132(115-135)$ & $132(105-135)$ & $0.83^{*}$ \\
SBP 30' & $140(110-150)$ & $135(105-155)$ & $0.19^{*}$ \\
SBP 60' & $133.50(110-150)$ & $130(105-150)$ & $0.35^{* *}$ \\
Initial DBP & $80(65-90)$ & $80(65-90)$ & $0.51^{*}$ \\
DBP 30' & $87.50(65-95)$ & $85(60-95)$ & $0.31^{*}$ \\
DBP 60' & $80(65-95)$ & $82.50(70-95)$ & $0.52^{*}$ \\
Initial HR & $78(64-100)$ & $80(68-100)$ & $0.46^{*}$ \\
HR 30' & $76(64-100)$ & $78(64-100)$ & $0.77^{*}$ \\
HR 60' & $76(60-104)$ & $80(64-96)$ & $0.69^{*}$ \\
Initial BSI & $2.59(1.49-4.60)$ & $2.81(1.17-4.38)$ & $0.73^{* *}$ \\
BSI 30' & $2.99(1.62-4.94)$ & $2.92(1.20-5.53)$ & $0.87^{*}$ \\
BSI 60' & $2.79(1.27-5.30)$ & $2.68(1.53-5.37)$ & $0.47^{*}$ \\
\hline Note: SBP: systolic blood pressure; DBP: diastolic blood pressure; \\
HR: heart rate (pulse rate); BSI: beta stiffness index; *Analyzed with \\
Wilcoxon; **Analyzed with pair T-test
\end{tabular}

Wilcoxon test results for data with abnormal distribution as well as pair T-test for data with normal distribution showed no significant differences among groups of controlled hypertension after arabica and robusta coffee administration in all variables.

\section{DISCUSSION}

\section{Characteristics of study subjects}

Samples in this study were 24 subjects of controlled hypertension and 24 normotensive subjects. Controlled hypertensive patients in this study were in median of 48.5 years old with minimum age of 35 years old and maximum of 60 years old. In this study, the prevalence of controlled hypertensive patients in women was higher than that in men. This is in accordance with the epidemiological data of basic health research (Riskesdas) in 2013 which stated that the prevalence of hypertension in women was higher than the prevalence of hypertension in men (Balitbangkes 2013). According to Frary et al (2005), the biggest caffeine consumers are men and women aged between 35 to 64 years old (Faraq et al 2010).

\section{Analysis results of differences in blood pressure and arterial stiffness after consuming arabica and robusta coffee in controlled hypertensive and normotensive groups}

Coffee is a drink that is widely consumed around the world. Therefore, the risks and benefits associated with coffee consumption are important to health workers and necessary to be understood by society (Nurminen 1999). Caffeine contained in coffee is the most active coffee substance which has been observed. Some studies suggested that elevated blood pressure after consuming coffee was due to caffeine's effect on peripheral vascular resistance rather than an increase in cardiac output (Hartley et al 2000). There is a tendency of idea about the role of aorta in the pathogenesis of increased blood pressure, especially systolic. Aorta and large arterial blood vessels have major function in cardiovascular system as a buffer organ. Large arteries support pressure changes due to intermittent blood injection from the ventricle to aorta. Aorta and large arterial blood vessels maintain coronary blood flow and avoid increased left ventricular afterload by absorbing some ventricular ejection energy at systolic and releasing it at diastolic. The pressure waves are reflected back from peripheral circulation along with forward wave. Furthermore, they produce typical aortic pressure waveform. Pulse wave velocity (PWV) is associated with arterial stiffness. Increased arterial stiffness is associated with increased cardiovascular risk (Mahmud \& Feely 2001). Arterial stiffness increases with age and is aggravated by conditions such as hypertension, diabetes mellitus, and kidney disease (Kaas 2005). Previous study by Hartley et al (2000) suggested that elevated blood pressure after caffeine was higher in hypertensive group than in normotensive group.

In this study, there was significant difference in systolic and diastolic blood pressure between controlled hypertensive and normotensive groups either at baseline or at 30 minutes and 60 minutes after consuming arabica and 
robusta coffee. The median increase in systolic blood pressure in controlled hypertensive patients was about 2-8 $\mathrm{mmHg}$ after comsuming arabica coffee and about 5 $\mathrm{mmHg}$ after consuming robusta coffee. The median increase in diastolic blood pressure in controlled hypertensive group was about $7 \mathrm{mmHg}$ after consuming arabica coffee and about 2-5 $\mathrm{mmHg}$ after consuming robusta coffee. The increased value of systolic and diastolic blood pressure in controlled hypertension group was higher that that in normotensive group. The value of increased systolic and diastolic blood pressure in this study was lower than those in a study that found an increase in systolic blood pressure of about 3-14 $\mathrm{mmHg}$ and diastolic blood pressure of about 4-13 $\mathrm{mmHg}$ after consuming a single dose $(200-250 \mathrm{mg}$ ) of caffeine in coffee, which was equivalent to 2 to 3 cups of coffee (Nurminen et al 1999). This study used less doses of coffee. Mahmud and Feely's (2001) study mentioned the possible role of caffeine that caused increased arterial stiffness in normotensive subjects.

In this study, there was significant difference in beta stiffness index between controlled hypertensive and normotensive groups at initial measurement, at 30 minutes and 60 minutes after arabica and robusta coffee administration. The beta stiffness index increases with age. Until now, there is no standard value of beta stiffness index. A study conducted by Mushabati in 2015 mentioned that pulse wave velocity in hypertensive subject was higher than in normotensive subject (Mushabati 2015). In this study, the median value of beta stiffness index in controlled hypertensive subjects was lower than those in other studies which obtained a mean of $3.04 \pm 1.6$ (Utantyo \& Pikir 2015).

\section{Analysis results of differences in variable data after consuming arabica or robusta coffee in controlled hypertensive patients}

A meta-analysis study by Mesas et al (2011) on the effects of coffee on blood pressure and cardiovascular disease in individuals with hypertension found that the use of 200-300 mg caffeine caused elevated blood pressure without considering whether antihypertensive treatment were given or not. This study used 10.6 grams coffee in which the caffein content in robusta coffee was twice higher than those in arabica coffee.

A meta-analysis study by Mesas et al (2011) also mentioned that there was an increase in systolic and diastolic blood pressures in the first 60 minutes after coffee consumption with a change in systolic blood pressure of $8.14 \mathrm{mHg}$ and a change in diastolic blood pressure of $5.75 \mathrm{mmHg}$. In this study, there were significant differences in systolic and diastolic blood pressures before coffee administration, at 30 minutes after consuming coffee, and 60 minutes after consuming coffee with arabica and robusta coffee in controlled hypertensive patients. In this study, the peak effect of coffee on systolic and diastolic blood pressures was achieved on average in 30th minute after coffee, and tended to decline thereafter. An et al's (2011) study on physiology effects of caffeine stated that there was no effect of caffeine consumption on pulse. Geethavani et al's (2014) study of the caffeine effects on pulse and blood pressure suggested that caffeine caused an increase in blood pressure and pulse rate.

This study showed that there was no significant difference in pulse rate before coffee administration, at 30 minutes after coffee administration, and at 60 minutes after coffee administration with both arabica and robusta coffee in controlled hypertensive patients. Coffee or caffeine consumption increased vascular resistance that indicated the effects of vasoconstrictors. This pressor effect was followed by minimal increase in pulse rate, and even the pulse did not rise significantly after caffeine consumption. This may be due to bradycardia reflex response to the effect/action of pressor or direct effect on the cardiac sinoatrial node. The activation of baroreceptor reflexes was supported by studies using spectral strength analysis, and there was an increase in parasympathetic neural activity observed on normotensive subjects. Sometimes, palpitations were associated with coffee consumption, and this may be due to an increase in alertness level (Nurminen et al 1999).

Various arterial stiffness measurement techniques have been widely developed. This study used two dimensional ultrasound measurement techniques with consideration of ease in terms of its application; clinically practical and fast, inexpensive, and reliable due to the use of beta stiffness index formula. The beta stiffness index is today a diagnostic tool of arterial stiffness which is popularized in various scientific journals because of its simplicity and practicality. The measurements are performed on the right common carotid central artery which then presents the level of stiffness of the entire arterial system of the body.

A study conducted by Vlachopoulos et al in 2006 about the effects of chronic coffee consumption on aortic stiffness in hypertensive patients stated that coffee consumption was not associated with aortic stiffness in hypertensive subjects who had never received therapy. However, Vlachopoulos et al in 2005 also found that chronic coffee consumption caused a harmful effect on aortic stiffness on normotensive subjects. In this study, there were significant differences in beta stiffness index before arabica coffee administration, at 30 minutes after arabica coffee administration, and at 60 minutes after 
arabica coffee administration in controlled hypertensive patients.

This study showed that there were no significant differences in overall variables (SBP, DBP, HR, and BSI) before and after arabica and robusta coffee administration in controlled hypertensive subjects. This study used two types of coffee with different levels of caffeine. The level of caffeine in arabica coffee was lower than that in robusta coffee. Caffeine is metabolized in the liver by elimination half-life of about 2-8 hours. Caffeine metabolism may be influenced by several factors, both genetic and lifestyle factors. The genetic factors included CYP1A2 polymorphic genetics and the different activities of CYP1A2 enzymes in both men and women. The lifestyle factors may increase or decrease CYP1A2 activity. Higher caffeine consumption will increase CYP1A2 activity, while contraceptive use decreases CYP1A2 activity. The subjects in this study were less homogeneous in which some of the factors mentioned earlier were difficult to exclude. Thus, it might have affected the results of this study.

\section{Limitations of the study}

This study had shortcomings and limitations, such as no randomization, blood pressure and echocardiographic examination of carotid stiffness using only one observer, and no intra-observation variability test.

\section{CONCLUSION}

There were significant differences in initial systolic blood pressure and systolic blood pressure at 30 minutes and 60 minutes after arabica ( $\mathrm{p}$ 0.002) and robusta $(\mathrm{p}$ 0.012 ) coffee consumption in controlled hypertensive patients. The median increase in systolic blood pressure was about 2-8 $\mathrm{mmHg}$ after consuming arabica coffee, and about $5 \mathrm{mmHg}$ after consuming robusta coffee. There were significant differences in baseline diastolic and diastolic blood pressures at 30 minutes and at 60 minutes after arabica ( $p$ 0.004) and robusta ( $p$ 0.025) coffee consumption in controlled hypertensive patients. The median increase in diastolic blood pressure was about $7 \mathrm{mmHg}$ after consuming arabica coffee and about 2-5 $\mathrm{mmHg}$ after consuming robusta coffee. There were significant differences in initial arterial stiffness, arterial stiffness at 30 minutes and at 60 minutes after consuming arabica coffee (0.018) in controlled hypertensive patients. There were no significant differences in initial arterial stiffness, arterial stiffness at 30 minutes and at 60 minutes after consuming robusta coffee (p 0.104) in controlled hypertensive patients. There were no significant differences in overall variables after treatment between arabica and robusta coffee in controlled hypertensive patients.

\section{REFERENCES}

AEKI-AICE. Konsumsi kopi domestik. Available from http://www.aeki-aice.org. Accessed March 20, 2015

An S, Dhanze $\mathrm{T}$, Debbie Li R, Vosberg A. (2011).Interaction of deception and caffeine and its physiological effects. University of Wisconsin, Madison, p 1-13

Balitbangkes (2013).Riset kesehatan dasar (Riskesdas) 2013. Jakarta, Depkes RI, p 1-268

Chou T (1992). Caffeine, coffee, and the medical consequences. Western Journal of Medicine 157, 544-553

Faraq NH, Whitsett TL, McKey BS, et al (2010). Caffeine and blood pressure response: Sex, age, and hormonal status. Journal of Women's Health 19, 1171-1176

Frary CD, Johnson RK, Wang MQ (2005). Food sources and intakes of caffeine in the diets of persons in the United States. J Am Diet Assoc. 105, 110-3

Geethavani G, Rameswarudu M, Reddy RR (2014). Effect of caffeine on heart rate and blood pressure. International Journal of Scientific and Research Publications, vol 4, pp. 1-2.

Geleijnse JM (2008). Habitual coffee consumption and blood pressure: an epidemiological perspective. Vascular Health and Risk Management 4, 963-970

Hartley TR, Sung BH, Pincomb GA, et al. (2000). Hypertension risk status and effect of caffeine on blood pressure. Hypertension 36, 137-141

Janzen SO (2010). Chemistry of coffee. Elsevier 3, 1085-1096

Kaas DA (2005). Ventricular arterial stiffening integrating the pathophysiology. Hypertension 46, 185193

Mahmud A, Feely J (2001). Acute effect of caffeine on arterial stiffness and aortic pressure waveform. Hypertension 38, 227-231

Mesas AE, Leon-Munoz LM, Rodriguez-Artalejo F, et al (2011). The effect of coffee on blood pressure and cardiovascular disease in hypertensive individuals: a systematic review and meta-analysis. The American Journal of Clinical Nutrition 94, 1113-1126

Mushabati F (2015). Carotid femoral pulse wave velocity and central blood pressure in normotensive and hypertensive participants at the university teaching hospital in Lusaka, Zambia. The University of Zambia School of Medicine, Department of Physiological Sciences Lusaka

Nurminen ML, Niittynen L, Korpela R, Vapaatalo H (1999). Coffee, caffeine and blood pressure: a critical review. European Journal of Clinical Nutrition 53, 831-839 
Patil H, Lavie CJ, O'Keefe JH, et al (2011). Cuppa joe: Friend or foe? Effects of chronic coffee consumption on cardiovascular and brain health. Science of Medicine 108, 339-346

Rahajeng E (2009). Prevalensi hipertensi dan determinannya di Indonesia. Majalah Kedokteran Indonesia $59,580-587$

Torre JJ, Bloomgargen Z.T, Dickey R.A, et al (2006). AACE medical guidelines for clinical practice for the diagnosis and treatment of hypertension.' Endocrine Practice 12, 193-222

Utantyo NR, Pikir BS (2015). Korelasi antara arterial stiffness dan left ventricular stiffness terhadap kapasitas fungsional pada penderita hipertensi terkontrol. Surabaya, Departemen Ilmu Penyakit Jantung dan Pembuluh Darah RS Dr. Soetomo, Universitas Airlangga

WHO (2013). A global brief on hypertension. Silent killer, global public health crisis 